\title{
PENDAMPINGAN PEMUDA DESA SUMBEREJO DALAM PENGUATAN MENTAL SPIRITUAL MELALUI MAJELIS DZIKIR BASMALAH
}

\author{
Ainun Najib \\ Universitas Ibrahimy Situbondo, Indonesia \\ adjie245@gmail.com
}

Abstract: The role of pesantren colleges has a big responsibility in fostering and developing the potential of the surrounding community, especially for the younger generation who become assets to continue struggles in the future. The threat of drying up spiritual values among the younger generation is getting away from behavior that is in accordance with the expected morality. So the youth mentoring program in strengthening mental-spirituality is one of the efforts to care for geranerasi through participatory transfromative social change actions. Preventive efforts to equip adolescents with religious knowledge and mental and spiritual strengthening, not only have a positive impact personally, but will also benefit the community around them. Together with stakeholders who have a significant role, this program emphasizes the assistance and empowerment of the community in understanding and resolving their own social problems, especially in the religious field. The continuity of the program which is carried out simultaneously will continue to be directed at developing the potential of future generations, while still integrating the roles and functions of the youth of the village of Sumberejo, which play an active role in spreading the 
da'wah of Islam rahmatan lil 'alamin.

Keyword: Mentoring, strengthening mental-spirituality, Majelis Dzikir Basmalah

\section{Pendahuluan}

\section{Isu dan Fokus Pengabdian}

Dunia remaja merupakan masa-masa yang sangat menentukan dalam memberi banyak pengalaman hidup. Masa remaja adalah masamasa labil bagi seseorang yang tumbuh dewasa untuk mencari jati dirinya. Mereka ingin mengetahui yang terbaik untuk masa depannya, namun tidak menutup kemungkinan pula justeru terjerumus dalam pergaulan yang dapat menghncurkan masa depan mereka. Gaya hidup yang berkaitan dengan perkembangan zaman dan teknologi, berpengaruh terhadap perkembangan kelangsungan hidup kaum remaja. Mereka menjadi sasaran ancaman peredaran narkoba, minumminuman keras, pergaulan bebas yang semakin hari semakin menghawatirkan. Keringnya nilai-nilai spiritualitas bagi para remaja menjadi salah satu faktor yang memudahkan mereka terjerumus dalam pergaulan yang tidak baik. Sehingga membawa dampak pada perilaku atau tindakan amoral dan asusila yang semakin meresahkan masyarakat.

Maraknya penyimpangan perilaku generasi muda tersebut, dapat 
membahayakan keberlangsungan hidup bangsa ini di kemudian hari. Karena pemuda sebagai generasi yang diharapkan menjadi penerus bangsa, semakin hari semakin rapuh. Oleh karena itu, menyelmatkan generasi muda sama halnya dengan menyelamatkan bangsa di masa yang akan datang dari ancaman dekadensi moral penerus perjuangannnya. Tidak terkecuali dengan masyarakat di Desa Sumberejo Kecamatan Bnayuputih Situbondo. Salah satu upaya yang mungkin dilakukan adalah upaya prefentif dengan membekali para remaja dengan pengetahuan keagamaan serta penguatan mental spiritual, tidak hanya memberikan dampak positif secara pribadi, melainkan juga akan memberikan maslahat kepada masyarakat di sekitarnya.

Fakta tersebut menjadi tantangan serius bagi Universitas Ibrahimy untuk mengkaji dan mengembangkan pola pengabdian masyarakat agar dapat menghasilkan sesuatu yang benar-benar bermanfaat dan dirasa nyata oleh masyarakat. Upaya yang dikembangkan adalah bentuk pengabdian yang diarahkan kepada pendampingan dan pemberdayaan masyarakat dalam memahami dan menyeselesaikan problem sosialnya, khususnya dibidang keagamaan. Untuk mewujudkan ide tersebut, dosen melakukan pengabdian pada masyarakat dengan memperkuat pendampingan di tengah-tengah masyarakat khususnya wilayah yang 
menjadi Desa binaan Universitas Ibrahimy.

Program ini adalah pendampingan masyarakat dalam penguatan pembangunan mental siritual. Hal yang menjadi fokus pendampingan adalah: Bagaimanakah pendampingan terhadap masyarakat pemuda Desa Sumberejo Melalui Majelis Dzikir Basmalah?

\section{Alasan Memilih Dampingan}

Penyusunan perencanaan program pengbadian kepada masyarakat adalah hal pertama yang dilakukan, yaitu dengan menyusun perencanaan yang akan dilaksanakan tim pengabdian selama selama proses pelaksanaan pendampingan. Penyusunan program didasarkan atas hasil observasi lapangan yang dilaksanakan bersamasama untuk mengetahui kondisi dan situasi serta masyarakat dampingan.

Sumberejo merupakan salah satu desa yang berada di kecamatan Banyuputih Situbondo Jawa Timur. Sebelum bernama Sumberejo, desa ini bernama Sumberjoyo. Desa Sumberejo terbagi ke dalam delapan dusun, yatiu Dusun Sukorejo Utara, Dusun Sukorejo Seatan, Dusun Krajan, Dusun Karangrejo, Dusun Sodung, Dusun Leduk, Dusun Lesong, dan Dusun Bendera. Rata-rata penduduknya bekerja sebagai petani, nelayan dan peternak. Selain itu, masyarakat desa Sumberejo juga banya yang menjadi pegawai swasta. 
Desa Sumberejo terdapat salah suatu Pondok Pesantren tertua dan terbesar di Indonesia, yaitu Pondok Pesantren Syalafiyah Syafi'iyah Sukorejo, yang merupakan salah satu pondok pesantren terbesar di dikabupaten Situbondo. Secara sosio historis Pondok Salafiyah Syafi iyah Sukorejo ini awalnya berupa hutan belantara yang membentang dari gunung baluran sampai wilayah Asembagus. Hutan belantara itu dikenal sangat angker karena dihuni oleh binatang buas dan para dedemit karenanya tidak ada satupun masyarakat yang berani memasuki hutan tersebut. Pada tahun 1328 H/ 1908 M, Kiai Syamsul Arifin atas saran Habib Musawa dan Kiai Asadullah dari semarang, membabat hutan lebat tersebut untuk kemudian dijadikan sebuah pesantren. Dipilihnya hutan tersebut bukan serta merta karena kehendak K.H.R. As'ad akan tetapi hasil dari Istikhoroh. Pondok ini menempati area seluas 11,9 ha dengan ciri kekhasannya yaitu memadukan antara sistem salaf dan sistem modern.

Upaya keras Kiai Syamsul Arifin akhirnya terwujud. Berdirilah sebuah pesantren kecil terdiri dari beberapa gubuk untuk difungsikan sebagai rumah, mushollah dan asrama santri yang waktu itu hanya ada beberapa orang. Pada masa perjuangan kemerdekaan, pesantren Sukorejo tidak hanya menjadi pusat belajar tapi juga sebagai pusat perjuangan kemerdekaan. Para pejuang banyak ditampung dipesantren, 
sekaligus sebagai markas penyusunan strategi melawan penjajah Sejak tahun 1914, pesantren kecil itu berkembang bersamaan dengan datangnya para santri dari wilayah sekitar keresidenan Besuki. Pada tahun itu pula, masyarakat pun mulai berdatangan untuk kemudian menetap didesa itu. Hutan yang telah dirambah itu berubah menjadi areal pertanian ladang dan kebun yang hasilnya mulai bisa dirasakan penduduk. Pergaulan penduduk dengan pesantren pun berlangsung harmonis Dalam upaya mewujudkan pendidikan modern sesuai dengan kebutuhan zaman, berbagai lembaga pendidikan kejuruan dan keahlian pun didirikan seperti sekolah menengah kejuruan (SMK), lembaga kader ahli fiqh, Ma'had aly dan Madrasatul Qur'an yang dijadikan sebagai lembaga kajian keislaman dan pendalaman ilmu- ilmu alQur'an.

Sebagai lembaga pendidikan keagamaan yang memiliki karakteristik khas Nusantara, secara substansial institusi pondok pesantren tidak mungkin bisa dilepaskan dari masyarakat, khususnya masyarakat pedesaan. Pondok pesantren tumbuh dan berkembang dari, oleh dan untuk masyarakat, dengan posisinya sebagai institusi yang berperan melakukan transformasi sosial bagi masyarakat yang berada di lingkungannya. Demikian halnya dengan eksistensi Pondok Pesantren Salafiyah Syafi'iyah Sukorejo, dengan figur Kiai yang tidak hanya 
sebagai figur tokoh agama, melainkan juga sekaligus sebagai tokoh masyarakat.

\section{Kondisi Dampingan Saat Ini}

Desa Sumberejo adalah salah satu desa yang menjadi bagian dari kecamatan Banyuputih, dengan luas wilayah mencapai $23.24 \mathrm{Km}^{2}$ dengan tingkat kepadatan penduduk mencapai 980 jiwa per $\mathrm{Km}^{2}{ }^{1}$ Sumberejo merupakan desa yang memiliki penduduk paling besar diantara desa-desa lainnya di kecamatan Banyuputih, yaitu berjumlah 22.766 Jiwa, dengan rincian 11.189 Laki-laki, dan 11.577 perempuan. $^{2}$

Secara kuantitas penduduk desa Sumberejo 99,89\% beragama Islam, namun secara kualitas keberagamaannya masih sangat beragam. Hal ini dibuktikan dengan perilaku sosial yang dapat mencerminkan nilai-nilai religiusitas masih relatif rendah. Khususnya di kalangan kaum muda yang masih cenderung ekspresif dalam setiap gaya hidup pergaulannya.

Para pemuda ini butuh perhatian dan binaan untuk dapat diarahkan kepada hal-hal yang beroirntasi lebih positif. Maka sudah sepatutnya menyelamatkan pergaulan mereka melalui pendampingan yang dapat mengarahkan kepada hal yang lebih baik dan bermanfaat.

1 Kecamatan Banyuputih dalam Angka 2019, (Badan Pusat Statistik Kabupaten Situbondo). hlm. 31

2 Ibid. hlm. 33 
Melalui program pengabdian kepada masyarakat yang diorientasikan kepada pemuda di desa Sumberejo, diharapkan akan menumbuhkan peningkatan tingkat keberagamaan mental piritual.

\section{Kondisi Dampingan yang Diharapkan}

Secara umum kondisi dampingan yang diharapkan pada program pengabdian masyarakat ini adalah keberdayaan masyarakat dalam meningkatkan kualitas spiritualitas pemuda melalui majelis dzikir. Oleh karenanya, kondisi dampingan yang diharapkan dalam pengabdian ini adalah:

a) Penguatan pemahaman akan pentingnya mematuhi hukum-hukum agama Islam, nilai-nilai badah, berakhlaq yang baik, serta kepekaan sosial terhadap masyarakat sekitar bagi para pemuda. Pemuda merupakan generasi emas yang perlu diselamatkan, sebagai generasi penerus perjuangan bangsa di masa yang akan datang.

b) Terbentuknya kelompok/simpul-simpul pemuda yang gemar untuk terus menigkatkan pengetahuan keagamaan, serta kegiatan-kegiatan sosial yang berorientasi pada kemaslahatan ummat, serta memiliki nilai-nilai ibadah.

c) Terbentuknya masyarakat yang bermartabat dengan bekal pengetahuan agama yang kuat. Sehingga tercipta suatu bangsa yang baldatun thoyyibatun wa robbun ghafur. 


\section{Metode}

\section{Strategi yang Digunakan}

Guna mengantisipasi dan menanggulangi probem-problem praktis di kalangan pemuda terhadap perubahan tatanan sosial masyarakat, maka proses pelaksanaan program pengabdian masyarakat ini dilaksanakan melalui beberapa strategi dengan siklus yang diarahkan pada peningkatan pemahaman tentang proses perubahan tatanan sosial yang dijalankan oleh kerangka kerja etik melalui cara-cara partisipatoris.

Maka model program pengabdian kepada masyarakat ini menggunakan Participatory Action Research (PAR) dalam bentuk penguatan masyarakat melalui kesadaran diri guna melakukan tindakan perubahan yang efektif menuju kondisi kehidupan sosial yang lebih baik. ${ }^{3}$

\section{Stakeholders yang Berperan}

stekeholders yang memilii peran signifikan dalam proses pelaksanaan program, yaitu Pemerintah Desa, Organisasi Sosial Keagamaan, sejumlah tokoh masyarakat, pondok pesantren Salafiyah Syafi'iyah Sukorejo, dan Universitas Ibrahimy.

3 Abdullah Faisal, dkk., Metode \& Teknik Kuliah Kerja Nyata Transformatif; Implementasi Participatory Action Research (PAR) \& Participatory Rural Appraisal (PRA) untuk. Aksi Perubaban Sosial, (P3M STAIN Surakarta, 2006), hlm. 69 
a. Unsur pemerintah desa, diharapkan membantu memfasilitasi para pemuda desa agar memiliki orientasi pada peningkatan nilai-nilai religiusitas, agar lebih menjamin terselenggaranya program pegabdian kepada masyarakat yang optimal sesuai dengan apa yang telah diproramkan dengan baik.

b. Organisasi Sosial Keagamaan, seperti IPNU, GP. Ansor, MWC NU Kecamatan Banyuputih, juga diharapkan dapat mensinergikan beberapa program yang memiliki kesesuaian tema dengan program pengabdian masyarakat ini, khususnya dalam bidang keagamaan dan mental spiritual.

c. Tokoh masyarakat yang memiliki pengaruh, diharapkan dapat membantu terlaksananya program dengan baik, serta terus menjaga kesinambungan dari apa yang telah dilakukan melalui program pengabdian masyarakat ini.

d. Pondok Pesantren Salafiyah Syafi'iyah Sukorejo Situbondo. Bentukbentuk keterlibatannya adalah, mendukung secara moril terhadap kegiatan pengabdian, memberikan masukan, saran, serta arahan kepada tim yang berkaitan dengan sosial keagamaan.

e. Universitas Ibrahimy, bentuk-bentuk keterlibatannya adalah: merencanakan, melaksanakan, dan memfasilitasi pelaksanaan program; melakukan pendampingan selama pelaksanaan program; 
melakukan evaluasi program; penyusunan laporan dan mendeseminasikan hasil kegiatan agar tetap terus berkesinambungan.

\section{Langkah-langkah dalam Pendampingan}

Rancangan kegiatan yang akan dijalankan disinergikan dengan hasil observasi lapangan dengan mengkaji lokasi dampingan, serta potensi-potensi yang dimiliki, dengan melibatkan stakeholders yang dipandang perlu. melalui tahapan ini dapat digambarkan perencanaan kegiatan yang akan dilakukan untuk tahap selanjutnya.

Kedua, tim melaksakan pengkajian secara mendalam terhadap problem rendahnya pemahaman dan pengamalan nilai-nilai agama di masyarakat, yang disesuaikan dengan hasil observasi terdahulu dan memetakannya dengan potensi atau kekuatan yang ada.

Langkah berikutnya adalah melakukan pemetaan berdasarkan kemampuan Sumber Daya Manusia yang dimiliki, untuk melakukan persuasi di kalangan pemuda agar program pengabdian yang direncakan dapat terlaksana dengan baik dan memperoleh hasisl sesuai dengan yang direncanakan. 


\section{Penyusunan Rencana Aksi Partisipatoris}

Setalah melakukan proses pemetaan awal yang juga melibatkan pihakpihak terkait dalam pendampingan ini, maka kegiatan pengabdian kepada masayarakat pemuda desa Sumberejo antara lain:

a. Melakukan Focus Group Discussion (FGD) dengan pengurus pondok Pesantren Salafiyah Syafi'iyah Sukorejo, aparat pemerintahan desa Sumberejo, beserta sejumlah tokoh masarakat yang menjadi rujukan dalam proses pelaksanaan pengabdian ini.

b. Membangun komunikasi dengan komunitas-komunitas pemuda dan masayarakat desa Sumberejo. Tahapan ini tim merancang format kegiatan yang menyesuaikan degan permasalahan yang ditemukan selama proses pemetaan awal, sehingga mudah mendeskripsikan arah program yang akan dilaksanakan.

\section{Melaksanakan Aksi}

Dalam melaksanakan program pengabdian masyarakat ini, aksi yang dilaksanakan adalah memberikan orientasi kapada narasumber pendamping tentang topik problem yang dihadapi masayarakat pemuda desa Sumberejo.

a. Memberikan argumentasi-argumentasi tentang pentingnya peran pemuda dalam mengawal lahirnya generasi terbaik di masa yang akan datang. 
b. Melakukan pendampingan dalam proses-proses pengambilan keputusan bersama, dan memfasilitasi pengambilan keputusan secara patisipatif. ${ }^{4}$

c. Melakukan pendampingan kepada narasumber pendamping, dalam penyampaian materi dan kegiatan aksi lainnya selama kegiatan pengabdian berlangsung.

\section{Bentuk Kegiatan Pendampingan dan Pembinaan}

Terdapat beberapa program kegiatan yang dilaksanakan dalam program pengabdian kepada masyarakat bersama pemuda desa Sumberejo yang fokus dan pengembangannuya dapat diklasifikasikan melalui tiga penguatan. Yaitu ranah kognitif (intelektual), afektif (emosional), dan psikomotorik (keterampilan), ${ }^{5}$ antara lain::

a. Dzikir Hizb Basmalah Berjamaah

Hizb Basmalah adalah salah satu aurad pembacaan kalimat-kalimat Basmalah, yang didahului dengan wasilah serta ditutup dengan do'a. pembacaan Hizb Basmalah berjamaah ini dilaksanakan dalam dua majlis, yaitu Majelis Dzikir Basmalah yang dilaksanakan setiap 41 hari, dan Majelis Dzikir Basmalah yang dilaksanakan secara rutin setiap dua pekan sekali. Majelis Dzikir Basmalah yang dilaksanakan

4 Sudiyono, dkk., Strategi Pembelajaran Partisipatori, (UIN-Malang Press, Malang, 2006), hlm. 53

5 Anju Dwivedi, Metodologi Pelatihan Partisipatif, (Pondok Edukasi, Yogyakarta, 2003), hlm. 2.

Vol. 3 No. 1, A p ri 12021 
setiap 41 hari dipimpin dan dipandu langsung oleh KHR. Ahmad Azaim Ibrahimy, sedangkan Majelis Dzikir Basmalah yang dilaksanakan dua pekan sekali dipimpin secara bergiliran oleh jamaah majlis.

Lokasi pelaksanaan pembacaan Hizb Basmalah berjamaah ini, baik pembacaan Hizb Basmalah yang 41 hari sekali maupun yang dua pekan sekali, dilakukan secara anjangsana bergilir di kediaman masing-masing jamaah. Sesekali pembacaan Hizb Basmalah berjamaah dilaksanakan di lokasi alam bebas, di pantai, pegunungan, dan lain sebagainya. Tujuannya adalah untuk lebih meningkatkan kecintaan serta mengagungkan Allah melalui semesta ciptaan-Nya.

b. Pengajian Kitab al-Mukhtar min Kalami al-Akhyar

Kitab al-Mukhtar min Kalam al-Akhyar merupakan salah satu karya terbaik Syaikh Muhammad bin Alawi Al-Maliki Al-Hasani AlMakki, ulama besar dari kalangan Ahlussunnah di kota Makkah. Kitab berbahasa Arab tersebut merupakan kumpulan kisah teladan para nabi serta orangorang shaleh yang penuh dengan hikmah. Pengajian Kitab al-Mukhtar min Kalami al-Akhyar bagi jamaah Majelis Dzikir basmalah dilaksanakan pada waktu yang sama dengan Dzikir 
Hizb Basmalah, yaitu setiap 41 hari sekali, yang dibacakan langsung oleh KHR. Ahmad Azaim Ibrahimy.

Pembacaan kitab al-Mukhtar min Kalami al-Akhyar disajikan dengan bahasa yang lugas, mengingat jamaah Majelis Dzikir Basmalah brsifat umum, serta memiliki tingkat pendidikan yang berbedabeda. Penyampaian materi diselingi dengan rangkaian hikmah lainnya yang dikontekstualisasikan dengan situasi terkini yang berkembang di masyarakat, baik yang berhubungan dengan isu regional, nasional, maupun global.

c. Pengajian Online

Maraknya dakwah-dakwah yang berorentasi pada radikalisme umat Islam, menjadi persoalan serius yang perlu terus dicarikan solusi. Gerakan dakwah kelompok-kelompok tersebut banyak menyasar kalangan kaum muslim muda, sehingga media dakwah yang digunakan adalah melalui media-media elektronik yang banyak menyebar melalui jejaring media sosial. Ketika kelompok ini telah berhasil menguasai media, maka tidak menutup kemungkinan di masa-masa yang akan datang berhasil mengikis integrasi nasionalisme kebangsaan di kalangan kaum muda akibat pemahaman keagamaan yang instant. 
Untuk membentengi gerakan-gerakan tersebut, perlu ada penyeimbang terhadap gerakan dakwah yang berorientasi pada radikalisme fundamental. Atas dasar itulah Majelis Dzikir Basmalah berinisiatif membentuk program dakwah melalui multimedia yang bertajuk Pengajian Online Majelis Dzikir Basmalah. Seluruh awak kru media Program Pengajian Online ini terdiri dari pemuda desa Sumberejo. Pengajian Online dibina oleh KHR. Ahmad Azaim Ibrahimy, dan secara berkesinambungan juga akan menghadirkan tokoh-tokoh agama lainnya. Pengajian Online Majelis Dzikir Basmalah ini dapat diikuti melalui:

1) Situs Internet : : mdbasmalah.com

2) Yotube Channel : Majelis Dzikir Basmalah

3) Akun Facebook : Majlis Dzikir Basmalah

4) Akun Twitter : :md_basmalah

5) Akun Instagram : mdbasmalah

d. Donasi Anak Yatim

Sebagai bentuk kepedulian terhadap sesama, Majelis Dzikir Basmalah juga memiliki program santunan bagi anak-anak yatim yang bertajuk Donasi Anak Yatim (DAY). Melalui program tersebut Majelis Dzikir Basmalah melakukan penggalangan dana secara berkala, yang tidak hanya terbatas kepada jamaah majlis saja, 
melainkan bagi masyarakat secara umum yang hendak mendermakan sebagian hartanya untuk anak yatim.

Program Donasi Anak Yatim menyalurkan bantuan berupa dana pendidikan, khususnya bagi anakanak yatim yang masih duduk di bangku SD dan SLTP. Secara bertahap program ini tidak hanya mengelola santunan berupa uang dan untuk anak yatim saja, namun juga barang-barang berharga lainnya yang dapat dihibahkan kepada para fakir miskin, khususnya warga desa Sumberejo Kecamatan Banyuputih Kabupaten Situbondo.

e. Usaha Ekonomi Kreatif

Kreatifitas pemuda pada biasanya selalu berkembang, mereka butuh sarana penyaluran agar tetap dapat berkreasi dan terus meningkat kreatifitasnya. Demikian halnya dengan para pemuda yang tergabung dalam Majelis Dzikir Basmalah, bakat dan ide-ide mereka sangat baik untuk diwujudkan. Maka kreatifitas mereka difasilitasi dalam berbagai usaha yang juga bisa mendatangkan keuntungan bersama. kegiatan ini juga laboratorium untuk melatih kemandirian dan kecakapan para jamaah dalam mengembangkan usaha nantinya.

Bentuk-bentuk usaha ekonomi kreatif yang dilakukan seperti: usaha sablon, sticker cutting, gantungan kunci, kopyah bordir, lampu hias, 
hiasan dinding, dan lain-lain. Hasil dari kreatifitas merekalah yang terus dikembangkan dalam bidang pengembangan ekonomi majelis, sehingga kegiatan-kegiatan Majelis Dzikir Basmalah dapat berjalan secara mandiri tanpa menggantungkan bantuan dari pihak lain.

\section{Hasil Dan Diskusi}

\section{Dampak Perubahan}

Program pengadian masyarakat dirasa telah membawa dampak perubahan kepada arah yang lebih baik, khususnya terhadap pemuda desa Sumberejo. Baik perilaku sosial maupun perilaku mental spiritual. Proses pelaksanaan pengabdian masyarakat berjalan sesuai dengan yang telah direncanakan, dan akan terus dikembangkan di masa-masa yang akan datang.

Kecintaan pemuda kepada majelis dzikir secara simultan akan membawa dampak kepada arah perubahan yang lebih positif. Pemuda yang identik dengan perkumpulan yang lebih berorientasi kepada halhal yang negatif, dapat terhindarkan dengan bergabungnya ke dalam majelis dzikir dengan berbagai program yang memberikan peningkatan pemahan keagamaan, serta diharapkan membawa perubahan pada perilaku mental spiritual sehari-hari, hari ini dan di masa yang akan datang. 
Keberlanjutan program ini akan terus diperhatikan, mengingat dampak positifnya telah dapat dirasakan secara nyata, baik bagi masyarakat desa Sumberejo khususnya di kalangan para pemuda, maupun bagi masyarakat luas yang dapat mengikuti program pengajian online yang diselenggarakan oleh Majelis Dzikir Basmalah. Bersama stakeholders yang memiliki peran signifikan, beberapa program telah dicanangkan untuk pengembangan program di masa yang akan datang, dengan tetap mengintegrasikan peran serta fungsi pemuda desa Sumberejo dalam menyebarkan dakwah Islam rahmatan lil 'alamin.

\section{Diskusi Keilmuan}

Dalam ajaran agama sangat diperhatikan aspek pendidikan moral atau pembentukan kepribadian. Karena terbentuknya watak dan kepribadian inilah yang sesungguhnya merupakan inti tujuan dari semua proses pergaulan antar sesama manusia di muka bumi. Kecerdasan intelektual akan menjadi tidak ada artinya jika tidak didukung dengan moral, watak dan kepribadian yang luhur. Hal ini sebagaimana dijelaskan oleh KH. Hasyim Asy'ari di dalam pengantar kitabnya Adab al-'Alim wa al-Muta'allim yang ia kutip dari Ibnu alMubarak: nahnu ila qalîl min al-adab ahwaj minnâ ila kathîr min al-'ilm (kami lebih membutuhkan adab [etika, moral, budi pekerti] meskipun 
sedikit dari pada [memiliki] banyak ilmu pengetahuan [tetapi tidak beradab]) ${ }^{6}$

Bagi masyarakat desa Sumberejo, Kiai merupakan "tokoh sentral" yang dikonsepsikan sebagai guru ideal yang patut untuk dijadikan teladan bagi segenap masyarakat, baik dalam masalah keilmuan maupun perilaku dan kepribadiannya. Dengan demikian, peran kyai tidak hanya terbatas pada memberikan pengajaran yang berorientasi pada pengembangan intelektualitas (kognisi) saja, tetapi juga memberikan bimbingan ruhani serta prilaku yang baik, membangun karakter yang kuat, berperilaku mulia sesuai dengan norma-norma ajaran agama (Islam) dan nilai-nilai etika, serta menghargai tradisi agar mereka dapat menjadi manusia seutuhnya di tengah-tengah masyarakat sesuai fitrah kemanusiaannya baik sebagai hamba Allah maupun selaku khalifah-Nya di muka bumi.

Masyarakat juga menjadikan Kiai sebagai sumber rujukan dalam memberikan legitimasi dalam segenap tindakan warganya, sudah barang tentu mempunyai dasar pijakan yang bersifat keagamaan dalam memberikan penilaian. Hal ini karena watak pemimpin agama dan warga masyarakatnya yang figh oreinted, selalu meletakkan kegiatan

${ }^{6}$ Hasyim Asy'ari, Adab al-'Alim wa al-Muta'allim, (Maktabah At-Turats Al-Islamy, Tebuireng Jombang, 1415 H), hlm. 10.

Vol. 3 No. 1, A pril 2021 
yang dilakukan dalam pola hitam-putih atau salah-benar menurut hukum Islam. ${ }^{7}$

Sebagai salah satu desa yang di dalamnya terdapat pondok pesantren, maka sudah sepatutnya masyarakat Sumberejo dapat mencerminkan nilai-nilai sebagaimana yang diajarkan dalam pendidikan pesantren, yang secara garis besar mengandung muatanmuatan yang dibedakan dalam 2 (dua) kategori. Kategori pertama adalah ajaran dasar yang merupakan referensi bagi landasan hidup berikut penyelesaiannya dalam mengatasi seluruh problematika kehidupan di tengah dinamika sosial-budaya, yang mempunyai nilai kebenaran bersifat mutlak dan tidak runtuh dalam segala perubahan zaman. Ajaran dasar ini mempunyai muatan-muatan nilai universal, yang mempunyai daya relevansi dalam segala tataran ruang dan waktu. Bahkan, ajaran ini memiliki legalitas sakral dan telah secara tuntas dikodifikasikan oleh para ulama salafus shalih, yakni berupa Al-Qur'an dan Sunnah Nabi.

Kategori kedua adalah ajaran-ajaran yang merupakan hasil interpretasi dan derivasi dari ajaran dasar di atas. Ajaran ini mengelaborasi muatan ajaran dasar dengan kecenderungan pada aspekaspek praktis-aplikatif. Maka masyarakat di sekitar pesantren menjadi

${ }^{7}$ KH. MA. Sahal Mahfudh, Nuansa Fiqih Sosial, (LKiS, Yogyakarta, 2003), hlm. 349. 
garda terdepan yang dipercaya mampu mengakomodir kebutuhan penyelesaian persoalan-persoalan sosial-keagamaan di lingkungannya. Tak hanya identik dengan makna keislaman, tetapi karena karakteristik eksistensial pesantren yang mengandung arti keaslian Indonesia (indigenous).

Sebagai indigenous, pesantren dan masyarakat di sekitarnya muncul dan berkembang dari pengalaman sosiologis di lingkungannya. Terdapat suatu hipotesa bahwa jika saja Indonesia tidak mengalami penjajahan, mungkin pertumbuhan sistem pendidikan di negeri ini akan mewarisi corak pendidikan ala pesantren.

Proses modernisasi sering tampak sebagai suatu perubahan yang memiliki dampak sangat mendasar dan mendalam pada struktur nilai yang telah berlaku dalam kehidupan di masyarakat. Tidak mustahil sering terjadi pergeseran nilai atas perkembangan modernisasi. Dalam kaitannya dengan permasalahan ini, kalangan kademis bersama pihak pesantren harus mampu memberikan motivasi dan arahan terhadap perkembangan yang ada, dan berupaya merangkum realitas kehidupan dalam jalinan nilai-nilai spiritual dan moralitas yang Islami.

Sebagai implikasi dari kepeduliannya terhadap permasalahan masyarakat ini, kalangan akademisi bersama pesantren akan dapat memberi arah perkembangan masyarakat dari aspek sosial, budaya, 
politik bahkan hingga ekonomi, yang ditindaklanjuti dengan kerja nyata dalam rangka "pencerahan" dan pemecahan masalah yang ditentukan dalam masyarakat. Terbukti, berbagai fatwa ataupun keputusan masa'il fiqhiyah yang lahir dari hasil pemikiran orang-orang pesantren tidak saja memberikan keputusan halal-haram, tetapi juga melihat realitas perkembangan kehidupan dan mencarikan jalan keluar, sehingga masyarakat tidak terus terperangkap dalam "kegelapan" dan keharaman.

Maka, simbiosis antara pesantren dengan masyarakat ini kemudian dikenal sebagai konsep penguatan civil society, ${ }^{8}$ dimana tugas pokok Kiai dan pesantren adalah mendorong masyarakat agar lebih memahami dirinya, karena pemahaman tersebut akan menghantarkan mereka untuk membangun dan menemukan jati diri dan dunia ini, sesuai dengan konsep yang dikehendaki oleh Sang Maha Pencipta, dan yang pasti juga selaras dengan kemaslahatan masyarakat/sosial.

${ }^{8}$ Civil Society disamping dimaknai masyarakat sipil, padanan kata lainnya yang sering digunakan adalah masyarakat beradab atau masyarakat berbudaya, masyarakat kewargaan dan masyarakat madani. Maksud masyarakat berbudaya sebagai padanan kata Civil Society adalah sebagai lawan masyarakat liar. Masyarakat berbudaya merujuk pada masyarakat yang saling menghargai nilai-nilai sosial kemanusiaan (termasuk dalam kehidupan sosial, budaya, politik dan ekonomi). Sementara, istilah masyarakat madani merujuk pada Madinah, sebuah kota yang sebelumnya bernama Yastrib di wilayah Arab, di mana masyarakat Islam di bawah kepemimpinan Nabi Muhammad di masa lalu pernah membangun peradaban yang tinggi. Lihat, Muhammad A. S. Hikam, Demokrasi dan Civil Society, (LP3ES, Jakarta, 1999), hlm. 15 .

Vo1. 3 No. 1, A pril 2021 


\section{Kesimpulan}

Melalui kegiatan pendampingan ini, diharapkan agar Universitas Ibrahimy Sukorejo tetap mengembangkan pengabdian pada masyarakat, khususnya yang berkaitan dengan penguatan pembangunan mental spiritual masyarakat, khususnya di kalangan para pemuda, sebagai generasi perjuangan bangsa. Dengan tetap menjalin keterlibatan stakeholders dari berbagai pihak yang dapat mempermudah terlaksananya program pengabdian kepada masyarakat secara baik dan terus berkesinambungan. Demikian sebagai bahan laporan dan bukti tertulis pelaksanaan kegiatan pengabdian kepada masyarakat di desa Sumberejo Kecamatan Banyuputih Kabupaten Situbondo yang dilaksanakan dalam bentuk pendampingan bagi para pemuda desa Sumberejo untuk meningkatkan mental spiritual melalui Majelis Dzikir Basmalah.

\section{Daftar Pustaka}

A. S. Hikam, Demokrasi dan Civil Society, LP3ES Jakarta:, 1999.

Abdullah Faisal, dkk., Metode $\mathcal{E}$ Teknik Kuliah Kerja Nyata Transformatif; Implementasi Participatory Action Research (PAR) \& Participatory Rural Appraisal (PRA) untuk Aksi Perubahan Sosial, P3M STAIN Surakarta, 2006.

Ainun Najib, dkk. Peradaban Sukorejo, Ikhtisar Perjalanan Satu Abad Pondok Pesantren Salafiyah Syafi'iyah Sukorejo Situbondo, Tim Penelitian Panitia Satu Abad P2S2, Sukorejo Situbondo, 2014. 
Ainun Najib, Pengembaraan Terakhir, Sejarah dan Perjuangan KHR. Syamsul Arifin, Pena Salsabila, Jember, 2016.

Anju Dwivedi, Metodologi Pelatihan Partisipatif, Pondok Edukasi, Yogyakarta, 2003.

Hasyim Asy'ari, Adab al-'Alim wa al-Muta'allim, Maktabah At-Turats AlIslamy, Tebuireng Jombang: $1415 \mathrm{H}$.

Kecamatan Banyuputih dalam Angka 2019, Badan Pusat Statistik Kabupaten Situbondo.

KH. MA. Sahal Mahfudh, Nuansa Fiqih Sosial, LKiS, Yogyakarta: 2003.

M. Hasan Basri, KHR. As'ad Syamsul Arifin, Riwayat Hidup dan Perjuangannya, CV. Sahabat Ilmu, Surabaya, 1994.

Profil

Desa Sumberejo

Banyuputih

Situbondo,

https://opensid.sumberejo.id/.

Sudiyono, dkk., Strategi Pembelajaran Partisipatori, UIN-Malang Press, Malang, 2006 
JURNAL

\section{As-Sidanah}

Vol. 03 No. 1, April 2021 